\title{
CHEMICAL CONTROL
}

\section{Susceptibility of Liriomyza sativae Blanchard (Diptera: Agromyzidae) melon populations to abamectin, cyromazine, and cyantraniliprole}

\author{
Glenda Damasceno ${ }^{1}$, Talia C. da Silva ${ }^{2}$, Oderlei Bernardi ${ }^{3}$, Tiago C. Da Costa-Lima ${ }^{4}$ \\ ${ }^{1}$ Federal Rural University of Pernambuco (UFRPE), Dom Manuel de Medeiros, Dois Irmãos, 52171-900, Recife, PE, Brazil. \\ glendabio.damasceno@gmail.com \\ ${ }^{2}$ Petrolina, PE, Brazil.talia-cordeiro@hotmail.com \\ ${ }^{3}$ Federal University of Santa Maria (UFSM), Cidade Universitária, Bairro Camobi 97.105-900, Santa Maria, RS, Brazil. \\ oderlei.bernardi@ufsm.br \\ ${ }^{4}$ Brazilian Agricultural Research Corporation (Embrapa Semi-Arid Region), Rodovia BR-428, Km 152, Zona Rural, 56302- \\ 970, Petrolina, PE, Brazil.tiago.lima@embrapa.br.
}

BioAssay 13: ba13001 (2022)

Suscetibilidade de populações de meloeiro de Liriomyza sativae Blanchard (Diptera: Agromyzidae) à abamectina, ciromazina e ciantraniliprole

\begin{abstract}
RESUMO - O melão encontra-se entre as frutas mais exportadas pelo Brasil. Dentre os problemas que dificultam o incremento de produtividade na cultura destaca-se a ocorrência da mosca-minadora, Liriomyza sativae (Blanchard) (Diptera: Agromyzidae). O controle químico é o mais utilizado para o manejo desta praga, porém, produtores têm relatado uma redução na suscetibilidade a inseticidas. Assim, o objetivo deste trabalho foi avaliar a suscetibilidade de populações de L. sativae aos inseticidas abamectina, ciromazina e ciantraniliprole coletadas em melão no nordeste do Brasil (Juazeiro, BA e Icapuí, $\mathrm{CE}$ ). $\mathrm{A} \mathrm{CL}_{50}$ (concentração letal média) dos inseticidas foi obtida em estudos em laboratório usando o método de bioensaio de imersão de folhas com larvas de L. sativae. Com base nos valores de $\mathrm{CL}_{50}$, não se observou diferenças na suscetibilidade das populações para os três inseticidas avaliados. Ambas as populações de L. sativae demonstraram baixa variação na suscetibilidade a abamectina, ciromazina e ciantraniliprole.
\end{abstract}

PALAVRAS-CHAVE: mosca-minadora, Cucumis melo, inseticidas

ABSTRACT - Melon is one of the most exported fruits from Brazil. The leafminer fly, Liriomyza sativae (Blanchard) (Diptera: Agromyzidae), is one of the major problems that negatively interfere in the productivity increase in this crop. Chemical control is the most adopted method for this pest; however, producers have reported reduced susceptibility to insecticides. Thus, this study aimed to evaluate the susceptibility of $L$. sativae larvae to abamectin, cyromazine, and cyantraniliprole from populations collected from two melon crop-producing regions in Northeast Brazil (Juazeiro, BA and Icapuí, CE). The insecticide's lethal concentration $50\left(\mathrm{LC}_{50}\right)$ was obtained in the laboratory using the leaf dip bioassay method with L. sativae larvae. No difference was observed in the $\mathrm{LC}_{50}$ between the populations for the three insecticides. Both populations showed low variation susceptibility for abamectin, cyromazine, and cyantraniliprole.

KEY WORDS: leafminer fly, Cucumis melo, insecticides.

Melons are one of the most exported fruits from Brazil, and in 2021, the country achieved U\$ 220 million in income (FAO 2021). The leafminer fly, Liriomyza sativae (Blanchard) (Diptera: Agromyzidae), is one of the major problems that negatively interfere in the productivity increase in this crop (Costa-Lima et al.2015). As the number of larvae per melon leaf increases, the photosynthesis rate, stomatal conductance, and transpiration decrease (Costa et al. 2017).

Synthetic insecticides are the most adopted method for L. sativae control by melon producers. However, the indiscriminate use of insecticides leads to select resistant populations and reduces the occurrence of natural enemies 
(Guantai et al. 2015, Gao et al. 2017). Resistant populations of the Liriomyza genus were already reported in China to abamectin (Fergunson 2004, Wei et al. 2014) and the United States to pyrethroids, abamectin, cyromazine, and spinosad (Macdonald 1991, Fergunson 2004).

In the melon-producing regions in Brazil, the problematic control of $L$. sativae with synthetic insecticides has led to studies aiming to search for different control methods, such as botanical insecticides (Oliveira et al. 2020) and biological control (Costa-Lima et al. 2019). Therefore, the present study aimed to evaluate the susceptibility of populations of $L$. sativae to three major synthetic insecticides used in melonproducing regions in Northeast Brazil.

\section{Material and Methods}

Bioassays were performed using two L. sativae populations collected from melon-producing regions in Juazeiro (BA) and Icapuí (CE). In the laboratory, the populations were reared over cowpea plants, according to Costa-Lima et al. (2017).

Three insecticides were evaluated, all registered for melon crops in Brazil to control the larval stage of leafminers. Increasing concentrations were used until a minimum of five points were obtained, with mortality ranging from zero to $100 \%$. Three products were evaluated with the following active ingredients and concentrations: abamectin (30 to 1,920 $\mathrm{ppm}$ ), cyromazine (75 to $1,200 \mathrm{ppm}$ ), and cyantraniliprole (120 to $2,000 \mathrm{ppm})$.

For the bioassays, cowpea plants [Vigna unguiculata (L.) Walp.] were exposed to $L$. sativae breeding cages for 24 hours. After the infestation, the plants were moved to a glasshouse. Every day, the plants were observed under stereomicroscopes for the presence of larvae. For the experiments, plants with larvae with less than 24 hours were used. Distilled water was used as the control. A $500 \mathrm{~mL}$ solution was prepared using distilled water for each insecticide concentration test. The method used was adapted from Ferguson (2004), with the solution immersion of leaves with $L$. sativae larvae for five seconds. After that, the plants were maintained in a climatized room, at $25 \pm 2{ }^{\circ} \mathrm{C}$, RH of $50 \pm 20 \%$, and a $12 \mathrm{~h}$ photophase. After five days, the number of dead larvae was counted using the stereomicroscope $(40 \mathrm{x})$ with transmitted light.

The experimental design was completely randomized. Each larva was considered one repetition, with a minimum of 100 repetitions per treatment. To assess the relative toxicity of insecticides against $L$. sativae populations, the $\mathrm{LC}_{50}$ lethal concentration and its $95 \%$ confidence interval (CI) were estimated. Therefore, the probit analysis was conducted with the Ecotoxicology package (Gama 2015) from R Software. Significant differences in susceptibility were stated between populations when its $95 \%$ confidence interval did not overlap.

\section{Results and Discussion}

No difference regarding the susceptibility of L. sativae was detected between the Juazeiro and Icapuí populations for the three insecticides evaluated. However, when comparing the $\mathrm{LC}_{50}$ between the three insecticides, the susceptibility to abamectin was lower. No difference was detected in the lethal toxicity between cyromazine and cyantraniliprole for both populations (Table 1).

The $\mathrm{LC}_{50}$ in the present study for abamectin ranged from 434.45 to $603.51 \mathrm{ppm}$. These are high values compared to results from resistant $L$. sativae populations in China ( $\mathrm{Gao} \mathrm{et}^{\mathrm{et}}$ al. 2017, Wei et al. 2014). In these studies, the highest $\mathrm{LC}_{50}$ for $L$. sativae was $1.00 \mathrm{ppm}$, obtained after a 16 selection cycle during 22 generations, from a population recovered from sponge cucumber in China (Wei et al. 2014). For the closely related species, Liriomyza trifolii (Burgess) (Diptera: Agromyzidae), the $\mathrm{LC}_{50}$ achieved $30.52 \mathrm{ppm}$ from a population obtained in cowpea plants in China (Gao et al. 2017). Abamectin has been registered for use in melon crops since the 1990 decade in Brazil for leafminer control (Agrofit 2021). The end of the patent had, consequently, new products with abamectin and reduced prices (Paiva 2011). Thus, abamectin became one of the major insecticides sprayed in melon crops for leafminer control. This long-term exposure to abamectin can be related to the low susceptibility observed for both $L$. sativae populations compared to the other two insecticides.

For cyromazine, the $\mathrm{LC}_{50}$ ranging from 127.17 to 159.17 ppm also was high compared to other studies with $L$. sativae (Gao et al. 2017, Wei et al. 2014). The highest $\mathrm{LC}_{50}$ found in these studies was $12.62 \mathrm{ppm}$, from $L$. sativae population collected from cowpea plants (Gao et al. 2017). The same authors obtained an $\mathrm{LC}_{50}$ of $71.81 \mathrm{ppm}$ for an L. trifolii population. Abamectin and cyromazine were the only registered insecticides recommended to control leafminer larvae in melon crops in Brazil for many years (Guimarães et al. 2005). This long-term exposure could also be related to the low susceptibility from both $L$. sativae populations to cyromazine.

Diamides are one of the most recent insecticides classes with a different mode of action (Teixeira \& Andaloro 2013). In Brazil, cyantraniliprole was registered in the 2010 decade to control L. sativae in melon crops (Agrofit 2021). There are no reports in the literature of Liriomyza spp. populations resistant to diamides or $\mathrm{LC}_{50}$ for leafminers populations.

The low susceptibility observed for both $L$. sativae populations for the tested insecticides could be related to resistance to the active ingredients and therefore explain the difficulty to control this pest in melon crops in northeast Brazil. Nonetheless, to elucidate these hypotheses, a study with more populations compared to a susceptible population would be necessary.

We conclude that there are no differences in susceptibility to abamectin, cyromazine, and cyantraniliprole by $L$. sativae populations from Icapuí and Juazeiro. However, abamectin showed lower toxicity for the populations tested than cyromazine and cyantraniliprole. In addition, high $\mathrm{LC}_{50}$ values were obtained for abamectin and cyromazine compared to previous studies. 
Table 1. Concentration-mortality response (ppm) of two L. sativae populations to three insecticides $\left(25 \pm 1^{\circ} \mathrm{C}, \mathrm{RH} 50 \pm\right.$ $20 \%$, and $12 \mathrm{~h}$ photophase).

\begin{tabular}{cccccccc} 
Active ingredient & Population & $\mathbf{n}$ & Slope $( \pm \mathbf{S E})$ & $\mathbf{C L}_{\mathbf{5 0}}(\mathbf{9 5} \% \mathbf{C I}) \mathbf{p p m}$ & $\begin{array}{c}\text { X2 } \\
\text { p-value }\end{array}$ \\
$\begin{array}{c}\text { Cyromazine } \\
(750 \mathrm{~g} / \mathrm{Kg})\end{array}$ & Juazeiro & 668 & $1,731 \pm 0,215$ & $159,17(120,35 ; 199,08)$ & 7,40 & 0,884 \\
\hline $\begin{array}{c}\text { Cyantraniliprole } \\
(100 \mathrm{~g} / \mathrm{L})\end{array}$ & Icapuí & 671 & $1,70 \pm 0,094$ & $127,17(90,54 ; 163,33)$ & 1,40 & 0,156 \\
\hline $\begin{array}{c}\text { Abamectin } \\
(18 \mathrm{~g} / \mathrm{L})\end{array}$ & Juazeiro & 671 & $1,83 \pm 0,275$ & $181,46(136,20 ; 230,08)$ & 8,99 & 0,970 \\
& Icapuí & 776 & $1,84 \pm 0,098$ & $156,70(11,55 ; 200,99)$ & 1,13 & 0,230 \\
\hline & Juazeiro & 847 & $1,404 \pm 0,173$ & $434,45(350,85-542,14)$ & 13,49 & 0,788 \\
\hline
\end{tabular}

$n=$ number of insects tested; $\mathrm{SE}=$ Standard error; $\mathrm{CL}_{50}=$ lethal concentration to cause $50 \%$ mortality; $\mathrm{CI} 95=95 \%$ confidence interval; $\mathrm{X} 2$ = Chi-square value; $\mathrm{p}$-value $=\mathrm{p}$-value for a given lethal concentration

\section{Cited literature}

Agrofit - Sistema de Agrotóxicos Fitossanitários. 2021. Available in: <https://agrofit.agricultura.gov.br/agrofit cons/principal agrofit_cons $>$. Acessed in 20 Oct. 2021.

Costa-Lima, T.C., A. de C. Silva \& J.R.P. Parra. 2015. Moscas-minadoras do gênero Liriomyza (Diptera: Agromyzidae): aspectos taxonômicos e biologia. Documentos, 268, Petrolina: Embrapa Semiárido.

Costa-Lima, T.C., L.D. Geremias, A.M. Begiato, M.C.M das Chagas \& J.R.P. Parra. 2017. Sistema de criação de parasitoide de mosca-minadora. Circular Técnica, 116, Petrolina: Embrapa Semiárido, 8p.

Costa-Lima, T.C, M.C.M. Chagas \& J.R.P. Parra. 2019. Comparing potential as biocontrol agents of two neotropical parasitoids of Liriomyza sativae. Neotrop. Entomol. 48: 660-667. doi: 10.1007/s13744-018-00667-0

Costa, E.M., R.M.O. Freitas, P.A.F. Silva \& E.L. Araujo. 2017. Determination of damaged leaf area and physiological responses of melon plants submitted to different levels of infestation by Liriomyza sativae. Hortic. Bras. 35: 571575. doi: $10.1590 / \mathrm{s} 0102-053620170415$

FAO - Food and Agriculture Organization of the United Nations. 2021. Available in: <https://www.fao.org $>$. Accessed in 01 Oct. 2021.

Fergunson, J.S. 2004. Development and stability of insecticide resistance in the leafminer Liriomyza trifolii (Diptera: Agromyzidae) to cyromazine, abamectin and spinosad. J. Econ. Entomol. 97: 112-119. doi: $\underline{10.1603 / 0022-0493-97.1 .112}$

Gama, J. 2015. Ecotoxicology: Methods for ecotoxicology. $\mathrm{R}$ package version 1.0.1.

Gao, Y.L., S. Reitz, Z.L. Xing, S. Ferguson \& Z.R. Lei.
2017. A decade of a leafminer invasion in China: Lessons learned. Pest Manag. Sci.73: 1775-1779. doi: 10.1002/ ps.4591

Guantai, M.M., C.P.K.O. Ogol, D. Salifu, J.M. Kasina, K.S. Akutse \& K.K.M. Fiaboe. 2015. Differential effects of pesticide applications on Liriomyza huidobrensis (Diptera: Agromyzidae) and its parasitoids on pea in Central Kenya. J. Econ. Entomol. 108: 662-671. doi: 10.1093/jee/tov006

Guimarães, J.A., F.R. Azevedo, R.B. Sobrinho \& A.L.M. Mesquita. 2005. Recomendações para o Manejo das Principais Pragas do Meloeiro na Região do SemiÁrido Nordestino. Comunicado Técnico, 107, Fortaleza: Embrapa Agroindústria Tropical, $6 \mathrm{p}$.

Macdonald, O.C. 1991. Responses of the alien leaf miners Liriomyza trifolii and Liriomyza huidobrensis (Diptera: Agromyzidae) to some pesticides scheduled for their control in the UK. Crop. Prot. 10: 509-514. doi: 10.1016/ $\underline{\mathrm{s} 0261-2194(91) 80142-3}$

Oliveira, A. C., T.C. da Costa-Lima, A.V. de Souza \& R. de C.R.G. Gervásio. 2020. Essential oils activity from plants of the Brazilian Caatinga on the vegetable leafminer. Pesqui. Agropecu. Trop. 50: 58313. doi: 10.1590/198340632020v5058313

Paiva, P.E.B. 2011. Abamectina em citros: 30 anos de uso. Citric Atual. 84: 18-21.

Teixeira, L.A. \& J.T. Andaloro. 2013. Diamide insecticides: Global efforts to address insect resistance stewardship challenges. Pestic Biochem Physiol 106: 76-78. doi: 10.1016/j.pestbp.2013.01.010

Wei, Q.B., Z.R. Lei, R. Nauen, D.C. Cai \& Y.L. Gao. 2014. Abamectin resistance in strains of vegetable leafminer, Liriomyza sativae (Diptera: Agromyzidae) is linked to elevated glutathione S-transferase activity. Insect Sci. 22: 243-250. doi: 10.1111/1744-7917.12080 